\title{
Cardiovascular risk factors and future risk of Alzheimer's disease
}

Renée FAG de Bruijn ${ }^{1,2}$ and M Arfan Ikram ${ }^{1,2,3^{*}}$

\begin{abstract}
Alzheimer's disease (AD) is the most common neurodegenerative disorder in elderly people, but there are still no curative options. Senile plaques and neurofibrillary tangles are considered hallmarks of AD, but cerebrovascular pathology is also common. In this review, we summarize findings on cardiovascular disease (CVD) and risk factors in the etiology of AD. Firstly, we discuss the association of clinical CVD (such as stroke and heart disease) and AD. Secondly, we summarize the relation between imaging makers of pre-clinical vascular disease and AD. Lastly, we discuss the association of cardiovascular risk factors and AD. We discuss both established cardiovascular risk factors and emerging putative risk factors, which exert their effect partly via CVD.
\end{abstract}

Keywords: Cardiovascular disease, Imaging markers, Risk factors, Dementia, Alzheimer's disease

\section{Introduction}

Alzheimer's disease (AD) is the most common subtype of dementia, and has a large patient and societal burden. $\mathrm{AD}$ has a complex and multifactorial etiology that involves senile plaques and neurofibrillary tangles [1]. Increasingly, the role of cardiovascular disease (CVD) is also being recognized as an important etiologic hallmark of $\mathrm{AD}$. Indeed, many studies have shown the importance of vascular pathology in AD [2-7]. As CVDs have established therapeutic options and the risk factors of CVD are modifiable, focusing on the association between vascular pathology and $\mathrm{AD}$ might provide pathways to prevent or delay $\mathrm{AD}$ in elderly individuals $[8,9]$. In this narrative review, we provide an overview of the current knowledge on the relation between $\mathrm{AD}$ and clinical CVDs, imaging markers of pre-clinical CVD, and established and emerging cardiovascular risk factors (Table 1).

\section{Review}

\section{Cardiovascular disease}

CVDs, such as stroke, atrial fibrillation, coronary heart disease (CHD), and heart failure are very common in elderly individuals and have regularly been linked to AD.

\footnotetext{
* Correspondence: m.a.ikram@erasmusmc.nl

'Department of Epidemiology, Erasmus MC University Medical Center,

Wytemaweg 80, 3015, CN, Rotterdam, the Netherlands

2Department of Neurology, Erasmus MC University Medical Center,

's-Gravendijkwal 230, 3015, CE, Rotterdam, the Netherlands

Full list of author information is available at the end of the article
}

This association might be due to shared risk factors between CVDs and AD, but there might also be a direct causal association as cardiac disease causes hypoperfusion and microemboli, which have been implicated in the etiology of $\mathrm{AD}[10,11]$. In the following sections, we discuss current evidence relating common CVDs with risk of $\mathrm{AD}$.

\section{Stroke}

Clinical stroke has often been associated with an increased risk of subsequent dementia, but this is by definition then termed 'post-stroke dementia' or 'vascular dementia' [12]. Such terminology hampers thorough investigation of the role of clinical stroke in $\mathrm{AD}$. Therefore, important evidence implicating stroke in the etiology of $\mathrm{AD}$ comes from studies investigating asymptomatic or 'silent' stroke, which are often lacunae. Numerous studies have shown that lacunae strongly increase the risk of dementia, including AD [13-15]. Moreover, white matter lesions, which also represent ischemic brain damage, are also associated with cognitive impairment and $\mathrm{AD}[16,17]$. These findings suggest that stroke is causally involved in the etiology of dementia. Mechanisms underlying this association include the following. Firstly, stroke causes loss of neuronal tissue, which might enhance the degenerative effect of neuronal tissue loss as a result of amyloid and tau pathology [15]. Secondly, it has been suggested that cerebrovascular disease directly influences amyloid pathology 
Table 1 List of potential vascular factors implicated in Alzheimer's disease

\begin{tabular}{llll}
\hline Cardiovascular disease & Pre-clinical markers of cardiovascular disease & Established cardiovascular risk factors & Emerging risk factors \\
\hline Stroke & Intima media thickness & $\begin{array}{l}\text { Blood pressure, hypertension, and arterial } \\
\text { stiffness }\end{array}$ & Inflammation \\
Atrial fibrillation & Carotid plaques & Glucose metabolism and diabetes mellitus & Chronic kidney disease \\
Coronary heart disease & Atherosclerotic calcification & Hypercholesterolemia & Thyroid function \\
Heart failure & Lacunae and white matter lesions & Smoking & Obesity \\
& Cerebral microbleeds & Non-adherence to the Mediterranean diet and \\
& Cerebral microinfarcts & low levels of physical activity & \\
& & Homocysteine & \\
& Retinal vascular changes & & \\
& Microstructural integrity and connectivity & &
\end{tabular}

as a result of accelerating amyloid $\beta$ production or hampering amyloid $\beta$ clearance $[3,18]$, although studies on these pathways remain inconsistent [3,18-21].

\section{Atrial fibrillation}

Several studies have shown that individuals with atrial fibrillation (AF) more often have $\mathrm{AD}$ and are at an increased risk of AD [22-24]. Because AF causes embolisms that could lead to stroke, the relation between AF and $\mathrm{AD}$ might be explained by clinical or silent stroke [10,25-27]. Accordingly, a meta-analysis showed that a consistent relation between AF and a higher risk of dementia was restricted to individuals with stroke [23]. However, another study found that stroke-free individuals with AF performed worse on memory and learning tasks, and had a reduced hippocampal volume [28]. Both memory function and hippocampal volume are strongly related to $\mathrm{AD}$, which suggests there might be additional pathways explaining the association between AF and AD [29]. One hypothesis is that cerebral hypoperfusion in AF causes damage to nerve cells, and thereby contributes to the etiology of AD [23,25-27]. Another hypothesis is that AF directly influences AD neuropathology, such as senile plaques and neurofibrillary tangles, but evidence for this explanation remains scarce [30].

\section{Coronary heart disease}

CHD is the most common type of heart disease, and one of the major causes of death worldwide [31]. CHD includes angina pectoris, myocardial infarction (MI), and coronary revascularization procedures. The relation between CHD and AD remains difficult to disentangle because of strong competing risks of death; several studies showed that CHD is related to cognitive impairment or AD [32,33], whereas others found no association [34,35]. The Rotterdam Study showed that unrecognized MI was associated with the risk of $\mathrm{AD}$, whereas recognized $\mathrm{MI}$ was not [36]. Explanations linking CHD with AD include shared etiology, as atherosclerosis plays an important role in both $\mathrm{CHD}$ and $\mathrm{AD}[26,27]$. This hypothesis is corroborated by findings from the Cardiovascular Health Study, which showed that peripheral artery disease, another manifestation of atherosclerosis, was also strongly associated with an increased risk of AD [32]. Furthermore, CHD might relate to AD through diminished cardiac function, hypoperfusion, and emboli [10,25-27].

\section{Heart failure}

Heart failure represents a condition in which the pumping function of the heart is diminished and unable to supply the body with sufficient blood flow. Heart failure has been associated with cognitive impairment and AD [37-39]. A Swedish study found that heart failure was related to an increased risk of dementia, including AD [37]. The same study also found that treatment with anti-hypertensive drugs slightly reduced this risk. The Framingham Offspring Study showed that even in individuals without clinical heart failure, lower cardiac function was related to lower brain volume, an important hallmark for dementia [40]. The pathways explaining the role of heart failure in the etiology of AD are similar to those of AF; heart failure results in hypoperfusion of the brain, which leads to hypoxia and damage to nerve cells [3,4,25-27]. Additionally, heart failure increases the risk of emboli and microvascular pathology, such as white matter lesions and lacunae, which in turn are related to an increased risk of dementia [10,25-27].

\section{Pre-clinical markers of cardiovascular disease}

Cardiovascular pathology gradually accumulates over years before manifesting as a clinical event. Similarly, AD pathology also accumulates over decades before clinical symptoms occur. Consequently, several studies have sought to investigate how such pre-clinical pathology relates to cognitive decline and AD.

\section{Pre-clinical markers of large vessel disease}

Using various imaging techniques, it is possible to assess markers of pre-clinical large vessel disease. Intima media thickness (IMT) and carotid plaque are measures of 
atherosclerosis in the carotid artery, which can be obtained via ultrasonography. Both IMT and carotid plaque are more prevalent in patients with dementia and AD than in cognitively healthy individuals [41]. Moreover, both measures are related to increased cognitive decline in patients with AD [42]. Additionally, several populationbased studies have shown that individuals with the highest IMT measures have an increased risk of incident dementia, including $\mathrm{AD}[32,43,44]$. Carotid plaque scores were also associated with an increased risk of AD in one study, but this association lacked statistical significance [44]. Another marker of pre-clinical large vessel disease is calcification volume in the atherosclerotic plaque, which can be assessed using computed tomography (CT). Although calcification is only part of the plaque, it is a suitable measure of the underlying plaque burden [45]. CT has the disadvantage of radiation exposure, but CT measures of atherosclerotic calcification are more observer-independent than ultrasonography measures. Few studies have investigated the relation between CT-derived atherosclerotic calcification and dementia, but some studies found that larger calcification volumes in the coronary arteries, aortic arch, and carotid arteries relate to worse cognitive performance $[46,47]$. Moreover, larger calcification volume was associated with smaller brain tissue volumes and worse microstructural integrity of the white matter, which are both factors related to an increased risk of AD [46]. Mechanisms linking carotid large vessel disease to $\mathrm{AD}$ include sub-clinical cerebral small vessel disease (see below), hypoperfusion, or shared etiology $[3,4,6]$.

\section{Pre-clinical markers of cerebral small vessel disease}

Abundant evidence shows that structural imaging markers of cerebral small vessel disease, such as lacunae and white matter lesions, are related to cognitive impairment or $\mathrm{AD}$ [15-17,48-50]. Additionally, brain atrophy, which is an established marker of dementia and $\mathrm{AD}$, is partly influenced by CVD [48,51,52]. Cerebral microbleeds (CMBs) are an emerging vascular marker with great promise for $\mathrm{AD}$ research. Both amyloid $\beta$ and vascular pathology are related to the etiology of $\mathrm{CMBs}$, and therefore a link between CMBs and incident AD seems plausible [53-55]. However, this association still needs to be confirmed in longitudinal studies. In recent years, it has also become possible to visualize cerebral microinfarcts using highfield magnetic resonance imaging (MRI) scanners, such as $7 \mathrm{~T}$ scanners. The role of these microinfarcts in AD remains unclear, but is expected to be the focus of research in coming years [56,57]. Although it is possible to measure markers of cerebral small vessel disease, direct visualization of the small cerebral arterioles in vivo remains difficult. Retinal imaging provides an easy tool to visualize retinal vessels that originate embryologically from the same tissues as cerebral vessels. Thus retinal imaging provides a possibility to study the small vessels of the brain in vivo. Retinal vessel diameter has been associated with white matter lesions, infarcts, brain atrophy, and an increased risk of vascular dementia [58-60]. Although a recent case-control study also found a link between $\mathrm{AD}$ and retinal microvascular changes [61], there is currently no evidence relating retinal vessels to an increased risk of AD longitudinally.

\section{Measures of brain connectivity}

In recent years, development of newer imaging techniques has allowed quantification of more subtle brain pathology such as changes in brain connectivity. Diffusion tensor imaging (DTI) assesses the microstructural integrity of the white matter, and studies have suggested that DTI markers reflect a very early stage of vascular brain pathology. Consequently, several studies have shown loss of microstructural integrity in early $\mathrm{AD}$ or even in mild cognitive impairment (MCI) [62-64]. However, longitudinal studies relating DTI markers to incident $\mathrm{AD}$ are still largely lacking. Another novel MRI technique is resting-state functional MRI, which measures brain function by functional connectivity at rest. Several studies have shown that functional connectivity is altered in patients with MCI and AD [65-69], but again, robust longitudinal data are still lacking. Moreover, the role of cardiovascular risk factors in functional MRI remains unclear.

\section{Cardiovascular risk factors}

In addition to clinical CVDs (see above), risk factors of CVD have also been implicated in AD. The causal pathway of these risk factors might be associated with clinical disease, but there is also evidence directly linking cardiovascular risk factors with AD.

\section{Blood pressure, hypertension, and arterial stiffness}

Several studies have related hypertension to brain atrophy, white matter lesions, and neurofibrillary tangles [70-72]. Therefore, an association between hypertension and $\mathrm{AD}$ is conceivable. Nonetheless, this association is complex and differs with age [73]. Several studies show mid-life hypertension to be related to an increased risk of $\mathrm{AD}$ [74-77], whereas other studies failed to find an association between late-life hypertension and dementia. In fact, some studies even suggest low blood pressure might be related to AD [73]. These inconsistencies have yet not been elucidated, but it is suggested that blood pressure decreases in the years before clinical onset of dementia because of reduced physical activity and lowered body weight. Further research is still necessary to verify this hypothesis [27].

A measure closely related to blood pressure and hypertension is arterial stiffness, which can be measured as 
increased pulse pressure or elevated pulse wave velocity. The difficulty in investigating arterial stiffness lies in the fact that it can be caused by hypertension as well as leading to hypertension $[78,79]$. Arterial stiffness results in increased pulsatile pressure, causing damage to the microvascular system of the brain [80], which in turn causes cognitive decline [80]. Indeed, some studies found a relation between higher pulse pressure or higher pulse wave velocity and an increased prevalence and risk of cognitive decline or $\mathrm{AD}$ [81-83]; however, others could not demonstrate such an association $[84,85]$.

\section{Glucose metabolism and diabetes mellitus}

Type 2 diabetes mellitus (T2DM) is a complex disorder, in which insulin resistance leads to higher circulating blood glucose levels, which in turn lead to microvascular damage in various organs. In the brain, T2DM has been associated with infarcts and atrophy [86,87]. Accordingly, many studies have confirmed that the risk of dementia and $\mathrm{AD}$ is higher in individuals with T2DM [88]. Furthermore, the risk of $\mathrm{AD}$ is also increased in individuals with borderline T2DM, that is, pre-diabetes [89]. Besides microvascular damage, other potential mechanisms relating T2DM with $\mathrm{AD}$ are direct neurotoxicity due to increased glucose and insulin levels. A higher circulating blood glucose level is toxic to nerve cells, as it causes protein glycation and oxidative stress [88]. Insulin is involved in amyloid $\beta$ clearance from the brain, and higher levels of insulin could disrupt this metabolism, leading to increased amyloid $\beta$ burden [88].

\section{Hypercholesterolemia}

Given the role of cholesterol in the clearance of amyloid $\beta$, hypercholesterolemia has been suggested as a risk factor for AD. Support for this hypothesis comes from a recent imaging study showing higher cholesterol levels to be related to higher amyloid $\beta$ levels [90]. Similarly, apolipoprotein $E$ \&4-carrier status, one of the most important genetic risk factors of $\mathrm{AD}$, is related to increased cholesterol levels [91]. However, results of epidemiological studies on the association between hypercholesterolemia and AD have been inconsistent. Some studies found that hypercholesterolemia in mid-life was associated with an increased risk of $\mathrm{AD}$, whereas in late life there was no association [92]. An explanation is that a high cholesterol level in mid-life is a risk factor of $\mathrm{AD}$, whereas lower cholesterol levels in late life probably reflect pre-clinical disease, as lifestyle and dietary habits change in individuals with sub-clinical dementia.

\section{Smoking}

Various longitudinal studies have established smoking as a risk factor for dementia and $\mathrm{AD}$ [93]. Both the Rotterdam Study and the Honolulu-Asia Aging Study found that the risk of dementia in smokers was higher than that in non-smokers [94,95]. Furthermore, the Honolulu-Asia Aging Study found that number of packyears was related to amyloid burden in the brain in a dose-response manner [95]. Smoking contributes to atherosclerosis, and has been related to cerebral small vessel disease $[49,96]$. Additionally, tobacco contains many neurotoxins, which might cause direct neuronal damage [97]. However, the exact mechanisms underlying the relation between smoking and dementia require further investigation.

\section{Obesity}

Similar to hypertension and increased cholesterol levels, the association between obesity and risk of dementia and $\mathrm{AD}$ changes with age [98-100]. Obesity in mid-life is associated with an increased risk of dementia and $\mathrm{AD}$, whereas in older age a higher body weight seems to have a protective effect $[100,101]$. Individuals with sub-clinical dementia gradually lose body weight due to altered lifestyle and lowered food intake, and thus low body weight might also be an early symptom of dementia [98-100]. In contrast, mid-life obesity increases the risk of many chronic diseases, including vascular diseases, and could be related to an increased risk of dementia and $A D$ via those pathways [101].

\section{Mediterranean diet and physical activity}

The Mediterranean diet is characterized by a high intake of vegetables, fruits, cereals, and unsaturated fatty acids, a moderate intake of fish, poultry, eggs, red wine, and dairy products, and a low intake of saturated fats and red, processed meats [102]. Adherence to a Mediterranean diet has shown to reduce vascular disease and vascular risk factors, and to lower inflammation and oxidative stress [103]. Two recent meta-analyses concluded that adherence to a Mediterranean diet might reduce the risk of AD $[104,105]$. However, the number of studies with long follow-up is limited, and further research is necessary to confirm the potential protective effect of the Mediterranean diet on AD.

Besides dietary habits, another potential modifiable factor to reduce AD risk is physical activity $[9,106]$. Physical activity is inversely associated with CVD and diabetes, and could therefore also reduce the risk of AD $[107,108]$. Alternatively, physical activity could have a direct protective effect on the risk of dementia, as it improves cerebral perfusion and increases neurogenesis [109,110]. Several epidemiological studies have associated a higher level of physical activity with a reduced risk of dementia or cognitive decline [111-115]. However, most of these studies had relatively short follow-up, and studies with long follow-up periods have yielded inconsistent results $[115,116]$. For both physical activity levels and 
the Mediterranean diet, the possibility of reverse causality explaining short-term associations needs to be considered [117].

\section{Homocysteine}

Plasma homocysteine levels reflect folate and vitamin B12 status, and are related to renal function. Increased homocysteine levels are associated with vascular disease, and might have an effect on amyloid $\beta$ and tau phosphorylation. Consequently, high plasma homocysteine levels have been related to an increased risk of AD [118]. Imaging and autopsy studies showed that increased homocysteine levels were associated with brain atrophy and neurofibrillary tangles $[119,120]$. However, not all studies concur with these results. A recent study found that plasma homocysteine levels were not related to $\mathrm{AD}$, after adjusting for folate or vitamin B12 deficiency and renal dysfunction [121]. Further studies are needed to unravel this association.

\section{Emerging risk factors}

In addition to the classic vascular risk factors, there are other emerging risk factors that have been implicated in $\mathrm{AD}$, partly by vascular mechanisms.

\section{Inflammation}

Various inflammatory markers have been related to an increased risk of dementia, including AD [122-124]. Astrocytes and microglia activate the neuronal immune system in response to pathogens such as infection and vascular pathology $[125,126]$. Several studies showed that senile plaques in the brains of patients with $A D$ and of $\mathrm{AD}$ transgenic mice models were surrounded by an increased number of activated microglia [127]. Amyloid $\beta$ also activates the neuronal immune system, and might cause a chronic inflammatory reaction that has a toxic effect on nerve cells [126]. Moreover, recent genetic studies have uncovered various genes for inflammation and immune response that seem to be associated with AD [128]. However, there have been no major populationbased cohort studies studying inflammation in AD, and trials studying the effect of immunotherapy on AD have not yet been successful [126]. Hence, further studies are required to elucidate the exact role of inflammation in $\mathrm{AD}$.

\section{Chronic kidney disease}

In recent years, various studies have focused on the association between chronic kidney disease (CKD) and cognitive decline or AD. Most [129-133], but not all [134] of these studies found that low kidney function was related to an increased risk of dementia, $\mathrm{AD}$, or cognitive decline. These inconsistencies might be due to methodological discrepancies: different measures of kidney function were used, and there was a large variation across the study populations examined [132]. Mechanisms linking CKD and dementia include shared risk factors (such as hypertension, arterial stiffness, smoking, and obesity) and direct consequences of CKD (such as chronic inflammation, hemodynamic changes, anemia, and uremic toxins) [129]. However, these pathways are not well established, and should be investigated further.

\section{Thyroid function}

Thyroid hormone is important for brain function, and thyroid dysfunction is a potentially reversible cause of cognitive impairment [135]. Thyroid hormone is involved in amyloid precursor protein (APP) regulation. Animal studies have shown that APP expression is increased in hypothyroidism, which leads to higher amyloid $\beta$ levels [135]. In addition, thyroid dysfunction is associated with $\mathrm{CVD}$, and could therefore influence AD pathology indirectly [135]. Lastly, thyroid hormone levels alter as a consequence of $\mathrm{AD}$ pathology through reduction in thyrotropin releasing hormone secretion [136]. Observational studies have shown both hypothyroidism and hyperthyroidism to be related to $\mathrm{AD}$, but not all studies could establish an association [136-140].

\section{Conclusion}

In conclusion, there is abundant and converging evidence showing that CVDs and cardiovascular risk factors play an important role in the etiology of AD. While for some of these factors the mechanisms linking to $\mathrm{AD}$ are clear, for others the association with $\mathrm{AD}$ is more complex and needs further research to be completely unraveled. Nevertheless, given that these vascular factors are currently the only known modifiable risk factors for $A D$, the possibility of intervening with these factors to prevent or delay AD merits more dedicated research.

\section{Abbreviations}

AD: Alzheimer's disease; AF: Atrial fibrillation; APP: Amyloid precursor protein; CHD: Coronary heart disease; CKD: Chronic kidney disease; CMBs: Cerebral microbleeds; CT: Computed tomography; CVD: cardiovascular disease; DTI: Diffusion tensor imaging; IMT: Intima media thickness; MCl: Mild cognitive impairment; MI: Myocardial infarction; MRI: Magnetic resonance imaging; T2DM: Type 2 diabetes mellitus.

\section{Competing interests}

The authors declare that they have no competing interests.

\section{Authors' contributions}

$\mathrm{RB}$ and MAl both made substantial contributions to conception and design of the manuscript, and were involved in drafting the manuscript and revising it critically for important intellectual content. Both authors read and approved the final manuscript.

\section{Acknowledgments}

MAI was supported by the Netherlands Heart Foundation (2012 T008), Internationale Stichting Alzheimer Onderzoek (grant number 12533), Erasmus MC Fellowship 2013, and MRACE grant from Erasmus MC. 


\section{Author details}

'Department of Epidemiology, Erasmus MC University Medical Center Wytemaweg 80, 3015, CN, Rotterdam, the Netherlands. 'Department of Neurology, Erasmus MC University Medical Center, 's-Gravendijkwal 230, 3015, CE, Rotterdam, the Netherlands. ${ }^{3}$ Department of Radiology, Erasmus MC University Medical Center, 's-Gravendijkwal 230, 3015, CE, Rotterdam, the Netherlands.

Received: 4 April 2014 Accepted: 15 July 2014

Published online: 11 November 2014

\section{References}

1. Ballard C, Gauthier S, Corbett A, Brayne C, Aarsland D, Jones E: Alzheimer's disease. Lancet 2011, 377:1019-1031.

2. Jagust W: Untangling vascular dementia. Lancet 2001, 358:2097-2098.

3. Iadecola C: The pathobiology of vascular dementia. Neuron 2013, 80:844-866.

4. de la Torre JC: Is Alzheimer's disease a neurodegenerative or a vascular disorder? Data, dogma, and dialectics. Lancet Neurol 2004, 3:184-190.

5. Hachinski V, Munoz DG: Cerebrovascular pathology in Alzheimer's disease: cause, effect or epiphenomenon? Ann N Y Acad Sci 1997, 826:1-6.

6. Kelleher RJ, Soiza RL: Evidence of endothelial dysfunction in the development of Alzheimer's disease: Is Alzheimer's a vascular disorder? Am J Cardiovasc Dis 2013, 3:197-226.

7. Hachinski V: Stroke and Alzheimer disease: fellow travelers or partners in crime? Arch Neurol 2011, 68:797-798.

8. de la Torre JC: Vascular risk factor detection and control may prevent Alzheimer's disease. Ageing Res Rev 2010, 9:218-225.

9. Middleton LE, Yaffe K: Promising strategies for the prevention of dementia. Arch Neurol 2009, 66:1210-1215.

10. Goldberg I, Auriel E, Russell D, Korczyn AD: Microembolism, silent brain infarcts and dementia. J Neuro/ Sci 2012, 322:250-253.

11. de la Torre JC: Cardiovascular risk factors promote brain hypoperfusion leading to cognitive decline and dementia. Cardiovasc Psychiatry Neurol 2012, 2012:367516.

12. Leys D, Henon H, Mackowiak-Cordoliani MA, Pasquier F: Poststroke dementia. Lancet Neurol 2005, 4:752-759.

13. Vermeer SE, Prins ND, den Heijer T, Hofman A, Koudstaal PJ, Breteler MM: Silent brain infarcts and the risk of dementia and cognitive decline. N Engl J Med 2003, 348:1215-1222.

14. Troncoso JC, Zonderman AB, Resnick SM, Crain B, Pletnikova O, O'Brien RJ: Effect of infarcts on dementia in the Baltimore longitudinal study of aging. Ann Neurol 2008, 64:168-176.

15. Snowdon DA, Greiner LH, Mortimer JA, Riley KP, Greiner PA, Markesbery WR: Brain infarction and the clinical expression of Alzheimer disease, the Nun Study. JAMA 1997, 277:813-817.

16. Inaba $M$, White $L$, Bell $C$, Chen $R$, Petrovitch $H$, Launer $L$, Abbott RD, Ross GW, Masaki K: White matter lesions on brain magnetic resonance imaging scan and 5-year cognitive decline: the Honolulu-Asia aging study. J Am Geriatr Soc 2011, 59:1484-1489.

17. Prins ND, van Dijk EJ, den Heijer T, Vermeer SE, Koudstaal PJ, Oudkerk M, Hofman A, Breteler MM: Cerebral white matter lesions and the risk of dementia. Arch Neurol 2004, 61:1531-1534.

18. Garcia-Alloza M, Gregory J, Kuchibhotla KV, Fine S, Wei Y, Ayata C, Frosch MP, Greenberg SM, Bacskai BJ: Cerebrovascular lesions induce transient beta-amyloid deposition. Brain 2011, 134:3697-3707.

19. Noh Y, Seo SW, Jeon S, Lee JM, Kim JH, Kim GH, Cho H, Yoon CW, Kim HJ, Ye BS, Kim ST, Choe YS, Lee KH, Kim JS, Ewers M, Weiner MW, Lee JH, Werring DJ, Kang DR, Kim CS, Na DL: White matter hyperintensities are associated with amyloid burden in APOE4 non-carriers. J Alzheimers Dis 2014, 40:877-886

20. Lee MJ, Seo SW, Na DL, Kim C, Park JH, Kim GH, Kim CH, Noh Y, Cho H, Kim HJ, Yoon CW, Ye BS, Chin J, Jeon S, Lee JM, Choe YS, Lee KH, Kim JS, Kim ST, Lee JH, Ewers M, Werring DJ, Weiner MW: Synergistic effects of ischemia and beta-amyloid burden on cognitive decline in patients with subcortical vascular mild cognitive impairment. JAMA Psychiatry 2014, 71:412-422

21. Launer $L$, Petrovitch $H$, Ross GW, Markesbery W, White LR: AD brain pathology: vascular origins? Results from the HAAS autopsy study. Neurobiol Aging 2008, 29:1587-1590.
22. Ott A, Breteler MM, de Bruyne MC, van Harskamp F, Grobbee DE, Hofman A: Atrial fibrillation and dementia in a population-based study, the Rotterdam Study. Stroke 1997, 28:316-321.

23. Kwok CS, Loke YK, Hale R, Potter JF, Myint PK: Atrial fibrillation and incidence of dementia: a systematic review and meta-analysis. Neurology 2011, 76:914-922.

24. Bunch TJ, Weiss JP, Crandall BG, May HT, Bair TL, Osborn JS, Anderson JL, Muhlestein JB, Horne BD, Lappe DL, Day JD: Atrial fibrillation is independently associated with senile, vascular, and Alzheimer's dementia. Heart Rhythm 2010, 7:433-437.

25. Muqtadar H, Testai FD, Gorelick PB: The dementia of cardiac disease. Curr Cardiol Rep 2012, 14:732-740.

26. Justin BN, Turek M, Hakim AM: Heart disease as a risk factor for dementia. Clin Epidemiol 2013, 5:135-145.

27. Duron $E$, Hanon O: Vascular risk factors, cognitive decline, and dementia. Vasc Health Risk Manag 2008, 4:363-381.

28. Knecht S, Oelschlager C, Duning T, Lohmann H, Albers J, Stehling C, Heinde W, Breithardt G, Berger K, Ringelstein EB, Kirchhof P, Wersching H: Atrial fibrillation in stroke-free patients is associated with memory impairment and hippocampal atrophy. Eur Heart J 2008, 29:2125-2132.

29. Jack CR Jr, Shiung MM, Weigand SD, O'Brien PC, Gunter JL, Boeve BF, Knopman DS, Smith GE, Ivnik RJ, Tangalos EG, Petersen RC: Brain atrophy rates predict subsequent clinical conversion in normal elderly and amnestic MCl. Neurology 2005, 65:1227-1231.

30. Dublin S, Anderson ML, Heckbert SR, Hubbard RA, Sonnen JA, Crane PK, Montine TJ, Larson EB: Neuropathologic changes associated with atrial fibrillation in a population-based autopsy cohort. J Gerontol A Biol Sci Med Sci 2013, 69:609-615.

31. Opie LH, Commerford PJ, Gersh BJ: Controversies in stable coronary artery disease. Lancet 2006, 367:69-78.

32. Newman AB, Fitzpatrick AL, Lopez $O$, Jackson S, Lyketsos C, Jagust W, Ives D, Dekosky ST, Kuller LH: Dementia and Alzheimer's disease incidence in relationship to cardiovascular disease in the Cardiovascular Health Study cohort. J Am Geriatr Soc 2005, 53:1101-1107.

33. Roberts RO, Knopman DS, Geda YE, Cha RH, Roger VL, Petersen RC: Coronary heart disease is associated with non-amnestic mild cognitive impairment. Neurobiol Aging 2010, 31:1894-1902.

34. Knopman DS, Petersen RC, Cha RH, Edland SD, Rocca WA: Coronary artery bypass grafting is not a risk factor for dementia or Alzheimer disease. Neurology 2005, 65:986-990.

35. Petrovitch $\mathrm{H}$, White L, Masaki KH, Ross GW, Abbott RD, Rodriguez BL, Lu G, Burchfiel CM, Blanchette PL, Curb JD: Influence of myocardial infarction, coronary artery bypass surgery, and stroke on cognitive impairment in late life. Am J Cardiol 1998, 81:1017-1021.

36. Ikram MA, van Oijen M, de Jong FJ, Kors JA, Koudstaal PJ, Hofman A Witteman JC, Breteler MM: Unrecognized myocardial infarction in relation to risk of dementia and cerebral small vessel disease. Stroke 2008, 39:1421-1426

37. Qiu C, Winblad B, Marengoni A, Klarin I, Fastbom J, Fratiglioni L: Heart failure and risk of dementia and Alzheimer disease: a population-based cohort study. Arch Intern Med 2006, 166:1003-1008.

38. Huijts M, van Oostenbrugge RJ, Duits A, Burkard T, Muzzarelli S, Maeder MT, Schindler R, Pfisterer ME, Brunner-La Rocca HP, Investigators T-C: Cognitive impairment in heart failure: results from the Trial of Intensified versus standard Medical therapy in Elderly patients with Congestive Heart Failure (TIME-CHF) randomized trial. Eur J Heart Fail 2013, 15:699-707.

39. Ganguli M, Fu B, Snitz BE, Hughes TF, Chang CC: Mild cognitive impairment: incidence and vascular risk factors in a population-based cohort. Neurology 2013, 80:2112-2120.

40. Jefferson AL, Himali JJ, Beiser AS, Au R, Massaro JM, Seshadri S, Gona P, Salton CJ, DeCarli C, O'Donnell CJ, Benjamin EJ, Wolf PA, Manning WJ: Cardiac index is associated with brain aging: the Framingham Heart Study. Circulation 2010, 122:690-697.

41. Hofman A, Ott A, Breteler MM, Bots ML, Slooter AJ, van Harskamp F, van Duijn CN, Van Broeckhoven C, Grobbee DE: Atherosclerosis, apolipoprotein $\mathrm{E}$, and prevalence of dementia and Alzheimer's disease in the Rotterdam Study. Lancet 1997, 349:151-154.

42. Silvestrini M, Gobbi B, Pasqualetti P, Bartolini M, Baruffaldi R, Lanciotti C, Cerqua R, Altamura C, Provinciali L, Vernieri F: Carotid atherosclerosis and cognitive decline in patients with Alzheimer's disease. Neurobiol Aging 2009, 30:1177-1183. 
43. van Oijen M, de Jong FJ, Witteman JC, Hofman A, Koudstaal PJ, Breteler MM: Atherosclerosis and risk for dementia. Ann Neurol 2007, 61:403-410.

44. Wendell CR, Waldstein SR, Ferrucci L, O'Brien RJ, Strait JB, Zonderman AB: Carotid atherosclerosis and prospective risk of dementia. Stroke 2012, 43:3319-3324

45. Rumberger JA, Simons DB, Fitzpatrick LA, Sheedy PF, Schwartz RS: Coronary artery calcium area by electron-beam computed tomography and coronary atherosclerotic plaque area, A histopathologic correlative study. Circulation 1995, 92:2157-2162.

46. Bos D, Vernooij MW, Elias-Smale SE, Verhaaren BF, Vrooman HA, Hofman A, Niessen WJ, Witteman JC, van der Lugt A, Ikram MA: Atherosclerotic calcification relates to cognitive function and to brain changes on magnetic resonance imaging. Alzheimers Dement 2012, 8:S104-S111.

47. Reis JP, Launer LJ, Terry JG, Loria CM, Zeki Al Hazzouri A, Sidney S, Yaffe K, Jacobs DR Jr, Whitlow CT, Zhu N, Carr JJ: Subclinical atherosclerotic calcification and cognitive functioning in middle-aged adults: the CARDIA study. Atherosclerosis 2013, 231:72-77.

48. Blum S, Luchsinger JA, Manly JJ, Schupf N, Stern Y, Brown TR, DeCarli C, Small SA, Mayeux R, Brickman AM: Memory after silent stroke: hippocampus and infarcts both matter. Neurology 2012, 78:38-46.

49. van Dijk EJ, Prins ND, Vrooman HA, Hofman A, Koudstaal PJ, Breteler MM Progression of cerebral small vessel disease in relation to risk factors and cognitive consequences: Rotterdam Scan study. Stroke 2008, 39:2712-2719

50. Jokinen H, Gouw AA, Madureira S, Ylikoski R, van Straaten EC, van der Flier WM, Barkhof F, Scheltens P, Fazekas F, Schmidt R, Verdelho A, Ferro JM, Pantoni L, Inzitari D, Erkinjuntti T, Group LS: Incident lacunes influence cognitive decline: the LADIS study. Neurology 2011, 76:1872-1878.

51. Cardenas VA, Reed B, Chao LL, Chui H, Sanossian N, DeCarli CC, Mack W, Kramer J, Hodis HN, Yan M, Buonocore MH, Carmichael O, Jagust WJ, Weiner MW: Associations among vascular risk factors, carotid atherosclerosis, and cortical volume and thickness in older adults. Stroke 2012, 43:2865-2870

52. den Heijer T, van der Lijn F, Ikram A, Koudstaal PJ, van der Lugt A, Krestin GP, Vrooman HA, Hofman A, Niessen WJ, Breteler MM: Vascular risk factors, apolipoprotein $E$, and hippocampal decline on magnetic resonance imaging over a 10-year follow-up. Alzheimers Dement 2012, 8:417-425.

53. Goos JD, Kester MI, Barkhof F, Klein M, Blankenstein MA, Scheltens P, van der Flier WM: Patients with Alzheimer disease with multiple microbleeds: relation with cerebrospinal fluid biomarkers and cognition. Stroke 2009, 40:3455-3460

54. Goos JD, Henneman WJ, Sluimer JD, Vrenken H, Sluimer IC, Barkhof F, Blankenstein MA, Scheltens PH, van der Flier WM: Incidence of cerebral microbleeds: a longitudinal study in a memory clinic population. Neurology 2010, 74:1954-1960.

55. Vernooij MW, van der Lugt A, Ikram MA, Wielopolski PA, Niessen WJ, Hofman A, Krestin GP, Breteler MM: Prevalence and risk factors of cerebral microbleeds: the Rotterdam Scan Study. Neurology 2008 70:1208-1214

56. van Rooden S, Goos JD, van Opstal AM, Versluis MJ, Webb AG, Blauw GJ, van der Flier WM, Scheltens P, Barkhof F, van Buchem MA, van der Grond J: Increased number of microinfarcts in Alzheimer disease at 7-T MR imaging. Radiology 2014, 270:205-211.

57. van Veluw SJ, Zwanenburg JJ, Engelen-Lee J, Spliet WG, Hendrikse J, Luijten PR, Biessels GJ: In vivo detection of cerebral cortical microinfarcts with high-resolution 7 T MRI. J Cereb Blood Flow Metab 2013, 33:322-329.

58. de Jong FJ, Schrijvers EM, Ikram MK, Koudstaal PJ, de Jong PT, Hofman A, Vingerling JR, Breteler MM: Retinal vascular caliber and risk of dementia: the Rotterdam study. Neurology 2011, 76:816-821.

59. Ikram MK, De Jong FJ, Van Dijk EJ, Prins ND, Hofman A, Breteler MM, De Jong PT: Retinal vessel diameters and cerebral small vessel disease: the Rotterdam Scan Study. Brain 2006, 129:182-188.

60. Ikram MK, de Jong FJ, Vernooij MW, Hofman A, Niessen WJ, van der Lugt A, Klaver CC, Ikram MA: Retinal vascular calibers associate differentially with cerebral gray matter and white matter atrophy. Alzheimer Dis Assoc Disord 2013, 27:351-355

61. Cheung CY, Ong YT, Ikram MK, Ong SY, Li X, Hilal S, Catindig JA, Venketasubramanian N, Yap P, Seow D, Chen CP, Wong TY: Microvascular network alterations in the retina of patients with Alzheimer's disease. Alzheimers Dement 2014, 10:135-142.
62. Sexton CE, Kalu UG, Filippini N, Mackay CE, Ebmeier KP: A meta-analysis of diffusion tensor imaging in mild cognitive impairment and Alzheimer's disease. Neurobiol Aging 2011, 32:2322 e2325-2318.

63. Wang JH, Lv PY, Wang HB, Li ZL, Li N, Sun ZY, Zhao BH, Huang Y: Diffusion tensor imaging measures of normal appearing white matter in patients who are aging, or have amnestic mild cognitive impairment, or Alzheimer's disease. J Clin Neurosci 2013, 20:1089-1094.

64. Scola E, Bozzali M, Agosta F, Magnani G, Franceschi M, Sormani MP Cercignani M, Pagani E, Falautano M, Filippi M, Falini A: A diffusion tensor MRI study of patients with $\mathrm{MCl}$ and $\mathrm{AD}$ with a 2-year clinical follow-up. J Neurol Neurosurg Psychiatry 2010, 81:798-805.

65. Binnewijzend MA, Schoonheim MM, Sanz-Arigita E, Wink AM, van der Flier WM, Tolboom N, Adriaanse SM, Damoiseaux JS, Scheltens P, van Berckel BN, Barkhof F: Resting-state fMRI changes in Alzheimer's disease and mild cognitive impairment. Neurobiol Aging 2012, 33:2018-2028.

66. Greicius MD, Srivastava G, Reiss AL, Menon V: Default-mode network activity distinguishes Alzheimer's disease from healthy aging: evidence from functional MRI. Proc Natl Acad Sci U S A 2004, 101:4637-4642.

67. Rombouts SA, Barkhof F, Goekoop R, Stam CJ, Scheltens P: Altered resting state networks in mild cognitive impairment and mild Alzheimer's disease: an fMRI study. Hum Brain Mapp 2005, 26:231-239.

68. Sheline $\mathrm{Yl}$, Raichle ME: Resting state functional connectivity in preclinical Alzheimer's disease. Biol Psychiatry 2013, 74:340-347.

69. Kenny ER, O'Brien JT, Firbank MJ, Blamire AM: Subcortical connectivity in dementia with Lewy bodies and Alzheimer's disease. Br J Psychiatry 2013, 203:209-214.

70. van Dijk EJ, Breteler MM, Schmidt R, Berger K, Nilsson LG, Oudkerk M, Pajak A, Sans S, de Ridder M, Dufouil C, Fuhrer R, Giampaoli S, Launer LJ, Hofman A, CASCADE Consortium: The association between blood pressure, hypertension, and cerebral white matter lesions: cardiovascular determinants of dementia study. Hypertension 2004, 44:625-630.

71. den Heijer T, Launer LJ, Prins ND, van Dijk EJ, Vermeer SE, Hofman A Koudstaal PJ, Breteler MM: Association between blood pressure, white matter lesions, and atrophy of the medial temporal lobe. Neurology 2005, 64:263-267.

72. Petrovitch $H$, White LR, Izmirilian G, Ross GW, Havlik RJ, Markesbery W, Nelson J, Davis DG, Hardman J, Foley DJ, Launer LJ: Midlife blood pressure and neuritic plaques, neurofibrillary tangles, and brain weight at death: the HAAS. Honolulu-Asia aging Study. Neurobiol Aging 2000, 21:57-62.

73. Qiu C, Winblad B, Fratiglioni L: The age-dependent relation of blood pressure to cognitive function and dementia. Lancet Neurol 2005, 4:487-499.

74. Launer LJ, Ross GW, Petrovitch H, Masaki K, Foley D, White LR, Havlik RJ: Midlife blood pressure and dementia: the Honolulu-Asia aging study. Neurobiol Aging 2000, 21:49-55.

75. Whitmer RA, Sidney S, Selby J, Johnston SC, Yaffe K: Midlife cardiovascular risk factors and risk of dementia in late life. Neurology 2005, 64:277-281.

76. Kivipelto M, Helkala EL, Laakso MP, Hanninen T, Hallikainen M, Alhainen K, livonen S, Mannermaa A, Tuomilehto J, Nissinen A, Soininen H: Apolipoprotein E epsilon4 allele, elevated midlife total cholesterol level, and high midlife systolic blood pressure are independent risk factors for late-life Alzheimer disease. Ann Intern Med 2002, 137:149-155.

77. Joas E, Backman K, Gustafson D, Ostling S, Waern M, Guo X, Skoog I: Blood pressure trajectories from midlife to late life in relation to dementia in women followed for 37 years. Hypertension 2012, 59:796-801.

78. Kaess BM, Rong J, Larson MG, Hamburg NM, Vita JA, Levy D, Benjamin EJ, Vasan RS, Mitchell GF: Aortic stiffness, blood pressure progression, and incident hypertension. JAMA 2012, 308:875-881.

79. Gepner AD, Korcarz CE, Colangelo LA, Hom EK, Tattersall MC, Astor BC, Kaufman JD, Liu K, Stein JH: Longitudinal effects of a decade of aging on carotid artery stiffness: the multiethnic study of atherosclerosis. Stroke 2014, 45:48-53.

80. O'Rourke MF, Safar ME: Relationship between aortic stiffening and microvascular disease in brain and kidney: cause and logic of therapy. Hypertension 2005, 46:200-204.

81. Hanon O, Haulon S, Lenoir H, Seux ML, Rigaud AS, Safar M, Girerd X, Forette F: Relationship between arterial stiffness and cognitive function in elderly subjects with complaints of memory loss. Stroke 2005, 36:2193-2197.

82. Waldstein SR, Rice SC, Thayer JF, Najjar SS, Scuteri A, Zonderman AB: Pulse pressure and pulse wave velocity are related to cognitive decline in the Baltimore Longitudinal Study of Aging. Hypertension 2008, 51:99-104. 
83. Qiu C, Winblad B, Viitanen M, Fratiglioni L: Pulse pressure and risk of Alzheimer disease in persons aged 75 years and older: a communitybased, longitudinal study. Stroke 2003, 34:594-599.

84. Poels MM, van Oijen M, Mattace-Raso FU, Hofman A, Koudstaal PJ, Witteman JC, Breteler MM: Arterial stiffness, cognitive decline, and risk of dementia: the Rotterdam study. Stroke 2007, 38:888-892.

85. Dhoat S, Ali K, Bulpitt CJ, Rajkumar C: Vascular compliance is reduced in vascular dementia and not in Alzheimer's disease. Age Ageing 2008, 37:653-659.

86. Schmidt R, Launer LJ, Nilsson LG, Pajak A, Sans S, Berger K, Breteler MM, de Ridder M, Dufouil C, Fuhrer R, Giampaoli S, Hofman A, Consortium C: Magnetic resonance imaging of the brain in diabetes: the Cardiovascular Determinants of Dementia (CASCADE) Study. Diabetes 2004, 53:687-692.

87. Peila R, Rodriguez BL, Launer LJ, Honolulu-Asia Aging S: Type 2 diabetes, APOE gene, and the risk for dementia and related pathologies: the Honolulu-Asia Aging Study. Diabetes 2002, 51:1256-1262.

88. Biessels GJ, Staekenborg S, Brunner E, Brayne C, Scheltens P: Risk of dementia in diabetes mellitus: a systematic review. Lancet Neurol 2006, 5:64-74.

89. Xu W, Qiu C, Winblad B, Fratiglioni L: The effect of borderline diabetes on the risk of dementia and Alzheimer's disease. Diabetes 2007, 56:211-216.

90. Reed B, Villeneuve S, Mack W, Decarli C, Chui HC, Jagust W: Associations between serum cholesterol levels and cerebral amyloidosis. JAMA Neurol 2014, 71:195-200.

91. Eichner JE, Dunn ST, Perveen G, Thompson DM, Stewart KE, Stroehla BC: Apolipoprotein E polymorphism and cardiovascular disease: a HuGE review. Am J Epidemiol 2002, 155:487-495.

92. Anstey KJ, Lipnicki DM, Low LF: Cholesterol as a risk factor for dementia and cognitive decline: a systematic review of prospective studies with meta-analysis. Am J Geriatr Psychiatry 2008, 16:343-354.

93. Anstey KJ, von Sanden C, Salim A, O'Kearney R: Smoking as a risk factor for dementia and cognitive decline: a meta-analysis of prospective studies. Am J Epidemiol 2007, 166:367-378.

94. Reitz C, den Heijer T, van Duijn C, Hofman A, Breteler MM: Relation between smoking and risk of dementia and Alzheimer disease: the Rotterdam Study. Neurology 2007, 69:998-1005.

95. Tyas SL, White LR, Petrovitch H, Webster Ross G, Foley DJ, Heimovitz HK, Launer LJ: Mid-life smoking and late-life dementia: the Honolulu-Asia Aging Study. Neurobiol Aging 2003, 24:589-596.

96. Messner B, Bernhard D: Smoking and cardiovascular disease: mechanisms of endothelial dysfunction and early atherogenesis. Arterioscler Thromb Vasc Biol 2014, 34:509-515.

97. Treweek JB, Dickerson TJ, Janda KD: Drugs of abuse that mediate advanced glycation end product formation: a chemical link to disease pathology. Acc Chem Res 2009, 42:659-669.

98. Besser LM, Gill DP, Monsell SE, Brenowitz W, Meranus DH, Kukull W, Gustafson DR: Body mass index, weight change, and clinical progression in mild cognitive impairment and Alzheimer disease. Alzheimer Dis Assoc Disord 2014, 28:36-43.

99. Gu Y, Scarmeas N, Cosentino S, Brandt J, Albert M, Blacker D, Dubois B, Stern Y: Change in body mass index before and after Alzheimer's disease onset. Curr Alzheimer Res. in press.

100. Tolppanen AM, Ngandu T, Kareholt I, Laatikainen T, Rusanen M, Soininen H, Kivipelto M: Midlife and late-life body mass index and late-life dementia: results from a prospective population-based cohort. J Alzheimers Dis 2014, 38:201-209.

101. Xu WL, Atti AR, Gatz M, Pedersen NL, Johansson B, Fratiglioni L: Midlife overweight and obesity increase late-life dementia risk: a populationbased twin study. Neurology 2011, 76:1568-1574.

102. Trichopoulou A, Costacou T, Bamia C, Trichopoulos D: Adherence to a Mediterranean diet and survival in a Greek population. N Engl J Med 2003, 348:2599-2608.

103. Frisardi V, Panza F, Seripa D, Imbimbo BP, Vendemiale G, Pilotto A, Solfrizzi $V$ : Nutraceutical properties of Mediterranean diet and cognitive decline: possible underlying mechanisms. J Alzheimers Dis 2010, 22:715-740

104. Psaltopoulou T, Sergentanis TN, Panagiotakos DB, Sergentanis IN, Kosti R, Scarmeas N: Mediterranean diet, stroke, cognitive impairment, and depression: a meta-analysis. Ann Neurol 2013, 74:580-591.

105. Singh B, Parsaik AK, Mielke MM, Erwin PJ, Knopman DS, Petersen RC, Roberts $\mathrm{RO}$ : Association of mediterranean diet with mild cognitive impairment and Alzheimer's disease: a systematic review and metaanalysis. J Alzheimers Dis 2014, 39:271-282.

106. Hamer M, Chida Y: Physical activity and risk of neurodegenerative disease: a systematic review of prospective evidence. Psychol Med 2009, 39:3-11.

107. Berlin JA, Colditz GA: A meta-analysis of physical activity in the prevention of coronary heart disease. Am J Epidemiol 1990, 132:612-628.

108. Helmrich SP, Ragland DR, Leung RW, Paffenbarger RS Jr: Physical activity and reduced occurrence of non-insulin-dependent diabetes mellitus. $N$ Engl J Med 1991, 325:147-152.

109. van Praag H, Christie BR, Sejnowski TJ, Gage FH: Running enhances neurogenesis, learning, and long-term potentiation in mice. Proc Natl Acad Sci U S A 1999, 96:13427-13431.

110. Pereira AC, Huddleston DE, Brickman AM, Sosunov AA, Hen R, McKhann GM, Sloan R, Gage FH, Brown TR, Small SA: An in vivo correlate of exerciseinduced neurogenesis in the adult dentate gyrus. Proc Natl Acad Sci U S A 2007, 104:5638-5643.

111. Buchman AS, Boyle PA, Yu L, Shah RC, Wilson RS, Bennett DA: Total daily physical activity and the risk of $A D$ and cognitive decline in older adults. Neurology 2012, 78:1323-1329.

112. Scarmeas N, Luchsinger JA, Schupf N, Brickman AM, Cosentino S, Tang MX Stern Y: Physical activity, diet, and risk of Alzheimer disease. JAMA 2009, 302:627-637.

113. Barnes DE, Blackwell T, Stone KL, Goldman SE, Hillier T, Yaffe K: Cognition in older women: the importance of daytime movement. J Am Geriatr Soc 2008, 56:1658-1664.

114. Middleton LE, Manini TM, Simonsick EM, Harris TB, Barnes DE, Tylavsky F, Brach JS, Everhart JE, Yaffe K: Activity energy expenditure and incident cognitive impairment in older adults. Arch Intern Med 2011, 171:1251-1257.

115. Rovio S, Kareholt I, Helkala EL, Viitanen M, Winblad B, Tuomilehto J, Soininen $\mathrm{H}$, Nissinen A, Kivipelto M: Leisure-time physical activity at midlife and the risk of dementia and Alzheimer's disease. Lancet Neurol 2005, 4:705-711.

116. Morgan GS, Gallacher J, Bayer A, Fish M, Ebrahim S, Ben-Shlomo Y: Physical activity in middle-age and dementia in later life: findings from a prospective cohort of men in Caerphilly, South Wales and a meta-analysis. J Alzheimers Dis 2012, 31:569-580.

117. de Bruijn RF, Schrijvers EM, de Groot KA, Witteman JC, Hofman A, Franco $\mathrm{OH}$, Koudstaal PJ, Ikram MA: The association between physical activity and dementia in an elderly population: the Rotterdam Study. Eur $J$ Epidemiol 2013, 28:277-283.

118. Seshadri S, Beiser A, Selhub J, Jacques PF, Rosenberg IH, D'Agostino RB, Wilson PW, Wolf PA: Plasma homocysteine as a risk factor for dementia and Alzheimer's disease. N Engl J Med 2002, 346:476-483.

119. den Heijer T, Vermeer SE, Clarke R, Oudkerk M, Koudstaal PJ, Hofman A, Breteler MM: Homocysteine and brain atrophy on MRI of non-demented elderly. Brain 2003, 126:170-175.

120. Hooshmand B, Polvikoski T, Kivipelto M, Tanskanen M, Myllykangas L, Erkinjuntti T, Makela M, Oinas M, Paetau A, Scheltens P, van Straaten EC, Sulkava R, Solomon A: Plasma homocysteine, Alzheimer and cerebrovascular pathology: a population-based autopsy study. Brain 2013, 136:2707-2716.

121. Nilsson K, Gustafson L, Hultberg B: Elevated plasma homocysteine level is not primarily related to Alzheimer's disease. Dement Geriatr Cogn Disord 2012, 34:121-127.

122. Engelhart MJ, Geerlings MI, Meijer J, Kiliaan A, Ruitenberg A, van Swieten JC, Stijnen T, Hofman A, Witteman JC, Breteler MM: Inflammatory proteins in plasma and the risk of dementia: the Rotterdam Study. Arch Neurol 2004, 61:668-672.

123. van Oijen M, van der Meer IM, Hofman A, Witteman JC, Koudstaal PJ, Breteler MM: Lipoprotein-associated phospholipase A2 is associated with risk of dementia. Ann Neurol 2006, 59:139-144.

124. van Oijen M, Witteman JC, Hofman A, Koudstaal PJ, Breteler MM: Fibrinogen is associated with an increased risk of Alzheimer disease and vascular dementia. Stroke 2005, 36:2637-2641.

125. Ferreira ST, Clarke JR, Bomfim TR, De Felice FG: Inflammation, defective insulin signaling, and neuronal dysfunction in Alzheimer's disease. Alzheimers Dement 2014, 10:S76-S83.

126. Serpente M, Bonsi R, Scarpini E, Galimberti D: Innate immune system and inflammation in Alzheimer's disease: from pathogenesis to treatment. Neuroimmunomodulation 2014, 21:79-87. 
127. Liu L, Chan C: The role of inflammasome in Alzheimer's disease. Ageing Res Rev 2014, 15:6-15.

128. Lambert JC, Ibrahim-Verbaas CA, Harold D, Naj AC, Sims R, Bellenguez $C$, DeStafano AL, Bis JC, Beecham GW, Grenier-Boley B, Russo G, Thorton-Wells TA, Jones N, Smith AV, Chouraki V, Thomas C, Ikram MA, Zelenika D, Vardarajan BN, Kamatani Y, Lin CF, Gerrish A, Schmidt H, Kunkle B, Dunstan ML, Ruiz A, Bihoreau MT, Choi SH, Reitz C, Pasquier F, et al: Meta-analysis of 74,046 individuals identifies 11 new susceptibility loci for Alzheimer's disease. Nat Genet 2013, 45:1452-1458.

129. Bugnicourt JM, Godefroy O, Chillon JM, Choukroun G, Massy ZA: Cognitive disorders and dementia in CKD: the neglected kidney-brain axis. J Am Soc Nephrol 2013, 24:353-363.

130. Miwa K, Tanaka M, Okazaki S, Furukado S, Yagita Y, Sakaguchi M, Mochizuki H, Kitagawa K: Chronic kidney disease is associated with dementia independent of cerebral small-vessel disease. Neurology 2014, 82:1051-1057.

131. Cheng KC, Chen YL, Lai SW, Mou CH, Tsai PY, Sung FC: Patients with chronic kidney disease are at an elevated risk of dementia: a populationbased cohort study in Taiwan. BMC Nephrol 2012, 13:129.

132. Etgen T, Chonchol M, Forstl H, Sander D: Chronic kidney disease and cognitive impairment: a systematic review and meta-analysis. Am J Nephrol 2012, 35:474-482.

133. Sasaki Y, Marioni R, Kasai M, Ishii H, Yamaguchi S, Meguro K: Chronic kidney disease: a risk factor for dementia onset: a population-based study, the Osaki-Tajiri Project. J Am Geriatr Soc 2011, 59:1175-1181.

134. Helmer C, Stengel B, Metzger M, Froissart M, Massy ZA, Tzourio C, Berr C, Dartigues JF: Chronic kidney disease, cognitive decline, and incident dementia: the 3C Study. Neurology 2011, 77:2043-2051.

135. Tan ZS, Vasan RS: Thyroid function and Alzheimer's disease. J Alzheimers Dis 2009, 16:503-507.

136. Tan ZS, Beiser A, Vasan RS, Au R, Auerbach S, Kiel DP, Wolf PA, Seshadri S: Thyroid function and the risk of Alzheimer disease: the Framingham Study. Arch Intern Med 2008, 168:1514-1520.

137. Forti P, Olivelli V, Rietti E, Maltoni B, Pirazzoli G, Gatti R, Gioia MG, Ravaglia G: Serum thyroid-stimulating hormone as a predictor of cognitive impairment in an elderly cohort. Gerontology 2012, 58:41-49.

138. de Jong FJ, Masaki K, Chen H, Remaley AT, Breteler MM, Petrovitch H, White $L R$, Launer $L$ : Thyroid function, the risk of dementia and neuropathologic changes: the Honolulu-Asia aging study. Neurobiol Aging 2009, 30:600-606.

139. de Jong FJ, den Heijer T, Visser TJ, de Rijke YB, Drexhage HA, Hofman A, Breteler MM: Thyroid hormones, dementia, and atrophy of the medial temporal lobe. J Clin Endocrinol Metab 2006, 91:2569-2573.

140. Kalmijn S, Mehta KM, Pols HA, Hofman A, Drexhage HA, Breteler MM: Subclinical hyperthyroidism and the risk of dementia, the Rotterdam study. Clin Endocrinol (Oxf) 2000, 53:733-737.

\section{Submit your next manuscript to BioMed Central and take full advantage of:}

- Convenient online submission

- Thorough peer review

- No space constraints or color figure charges

- Immediate publication on acceptance

- Inclusion in PubMed, CAS, Scopus and Google Scholar

- Research which is freely available for redistribution

Submit your manuscript at www.biomedcentral.com/submit
C BioMed Central 